Final Draft of the original manuscript:

Wagner, D. and Liebner, S. (2009) Global Warming and Carbon Dynamics in Permafrost Soils: Methane Production and Oxidation. In: R. Margesin (ed.), Permafrost Soils. Soil Biology 16, Springer Berlin, pp 219-236.

ISBN 978-3-540-69370-3 (www.springer.com) 


\title{
15. Global Warming and Carbon Dynamics in Permafrost Soils: Methane Production and Oxidation
}

\author{
Dirk Wagner and Susanne Liebner \\ Alfred Wegener Institute for Polar and Marine Research, Research Unit \\ Potsdam, Telegrafenberg A45, 14473 Potsdam, Germany \\ Phone: +49 331288 2159, FAX: +49 3312882137 \\ Email: Dirk.Wagner@awi.de
}

\begin{abstract}
The Arctic plays a key role in the Earth's climate system, because global warming is predicted to be most pronounced at high latitudes, and one third of the global carbon pool is stored in ecosystems of the northern latitudes. The degradation of permafrost and the associated intensified release of methane, a climate-relevant trace gas, represent potential environmental hazards. The microorganisms driving methane production and oxidation in Arctic permafrost soils have remained poorly investigated. Their population structure and reaction to environmental change is largely unknown, which means that also an important part of the process knowledge on methane fluxes in permafrost ecosystems is far from completely understood. This hampers prediction of the effects of climate warming on arctic methane fluxes. Further research on the stability of the methane cycling communities is therefore highly important for understanding the effects of a warming Arctic on the global climate. This review first examines the methane cycle in permafrost soils and the involved microorganisms. It then describes some aspects of the potential impact of global warming on the methanogenic and methanotrophic communities.
\end{abstract}

\subsection{Introduction}

A better understanding of the global terrestrial carbon cycle has become policy imperative, both nationally and worldwide. The Kyoto Protocol recognizes the role of terrestrial systems as carbon sinks and sources. Terrestrial and sub-marine permafrost is identified as one of the most vulnerable carbon pools of the Earth system (Osterkamp 2001; Zimov et al. 2006). About one third of the global soil carbon is preserved in northern latitudes (Gorham 1991), mainly in huge layers of frozen ground, which underlay around $24 \%$ of the exposed land area of the northern hemisphere (Zhang et al. 1999). This carbon reservoir is of global climatic 
importance, in particular due to the currently observed climate changes in the Arctic (IPCC 2007; see Chapters 1 and 15.4).

Thawing of permafrost could release large quantities of greenhouse gases into the atmosphere, thus further increasing global warming and transforming the Arctic tundra ecosystems from a carbon sink to a carbon source (Oechel et al. 1993). Trace gas fluxes from permafrost ecosystems are influenced by a number of biotic and abiotic parameters (Figure 15.1). The decomposition of soil organic matter and the generation of greenhouse gases results from microbial activity which is affected by habitat characteristics (soil parameters) and by climate-related properties (forcing parameters). The way of gas transport determines the ratio between methane and carbon dioxide emission to the atmosphere. However, the processes of carbon release, their spatial distribution and their climate dependency are not yet adequately quantified and understood.

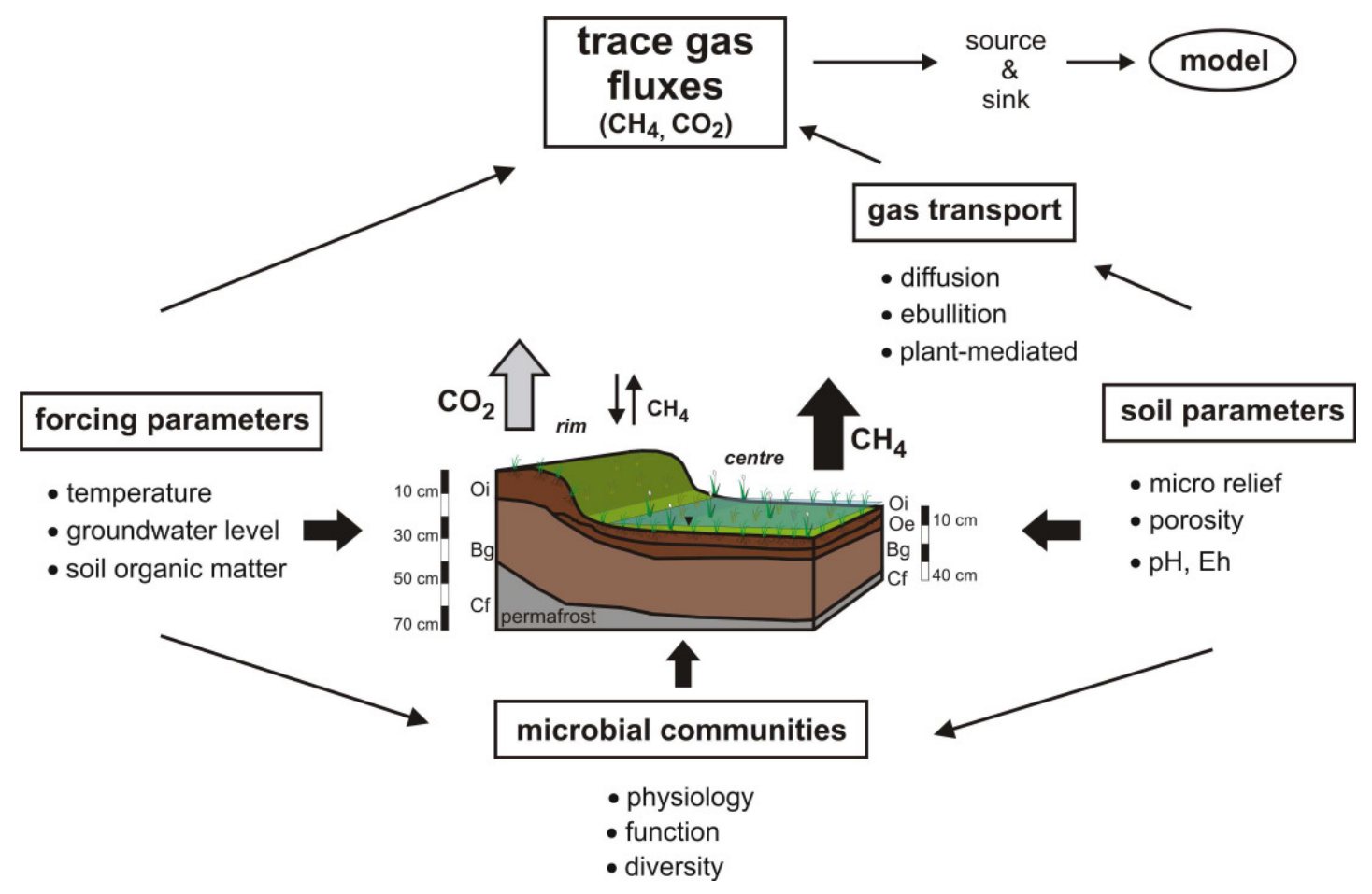

Fig. 15.1 Schematic view of the process variables influencing the formation, transport, and release of climate-relevant trace gases in permafrost soils.

The world-wide wetland area has a size of about $5.5 \times 10^{6} \mathrm{~km}^{2}$ (Aselman and Crutzen 1989). About half of it is located in high-latitudes of the northern hemisphere $\left(>50^{\circ} \mathrm{N}\right)$. The atmospheric input of methane from tundra soils of this region was estimated to vary between 17 and $42 \mathrm{Tg} \mathrm{CH}_{4} \mathrm{yr}^{-1}$ (Whalen and Reeburgh 1992; Cao 
et al 1996; Joabsson and Christensen 2001), corresponding to about $25 \%$ of the methane emission from natural sources (Fung et al. 1991).

In the last decades, numerous studies on methane fluxes were focused on tundra environments in Northern America and Scandinavia (e.g. Svensson and Rosswall 1984; Whalen and Reeburgh 1988; Bartlett et al. 1992; Liblik et al. 1997; Reeburgh et al. 1998; Christensen et al. 2000). Since the political changes in the former Soviet Union in the early nineties, the large permafrost areas of Russia were integrated into the circum-arctic flux studies (e.g. Christensen et al. 1995; Samarkin et al. 1999; Panikov and Dedysh 2000; Tsuyuzaki et al. 2001; Wagner et al. 2003; Corradi et al. 2005; Kutzbach et al. 2007; Wille et al. 2008). All these studies revealed temporal and spatial variability of methane fluxes, ranging between -1.9 and $360 \mathrm{mg} \mathrm{CH}_{4} \mathrm{~m}^{-2} \mathrm{~d}^{-1}$. To understand these dramatic fluctuations, some studies focused on the environmental conditions and soil characteristics, comprising the water table position, soil moisture and temperature, type of substrate and vegetation as well as availability of organic carbon (e.g. Torn and Chapin 1993; Vourlitis et al. 1993; Bubier et al. 1995; Oberbauer et al. 1998; Joabsson et al. 1999; Yavitt et al. 2000). These factors influence the methane dynamics of tundra environments. Although 80 to $90 \%$ of total methane emissions originate from microbial activity (Ehhalt and Schmidt 1978), only a few investigations dealt with methane production and methane oxidation caused by microbiological processes in the course of carbon dynamics (Slobodkin et al. 1992; Vecherskaya et al. 1993; Samarkin et al. 1994; Schimel and Gulledge 1998; Segers 1998; Frenzel and Karofeld 2000; Høj et al. 2005; Wagner et al. 2005; Liebner and Wagner 2007; Metje and Frenzel 2007).

This review first examines the processes of the methane cycle in permafrost soils. It then describes the methane-cycling microorganisms including possible impacts of global warming on their structure and function.

\subsection{Methane Cycle in Permafrost Soils}

The carbon pool estimates for permafrost soils vary between 4 and $110 \mathrm{~kg} \mathrm{C}$ $\mathrm{m}^{-2}$ (e.g. Schell and Ziemann 1983; Tarnocai and Smith 1992; Michaelson et al. 1996). These large variations can be attributed to different soil types (from mineral to peaty soils) and varying depths of measurements (from the upper few centimeters to $1 \mathrm{~m}$ depth). Permafrost soils can function as both a source and a sink for carbon dioxide and methane (Figure 15.2). Under anaerobic conditions, caused by flooding of the permafrost soils and the effect of backwater above the permafrost table, the mineralization of organic matter can only be realized stepwise by specialized microorganisms of the so called anaerobic food chain (Schink and Stams 2006). Important intermediates of the organic matter decomposition are hydrogen, carbon dioxide and acetate, which can be further reduced to methane (methanogenesis) by 
methanogenic archaea (see Chapter 15.3.1). The fermentation of carbon by microorganisms runs much slower than the oxidative respiration. As a result of the prolonged anaerobic conditions and low in situ temperatures of permafrost soils organic matter accumulates (peat formation) in these environments.

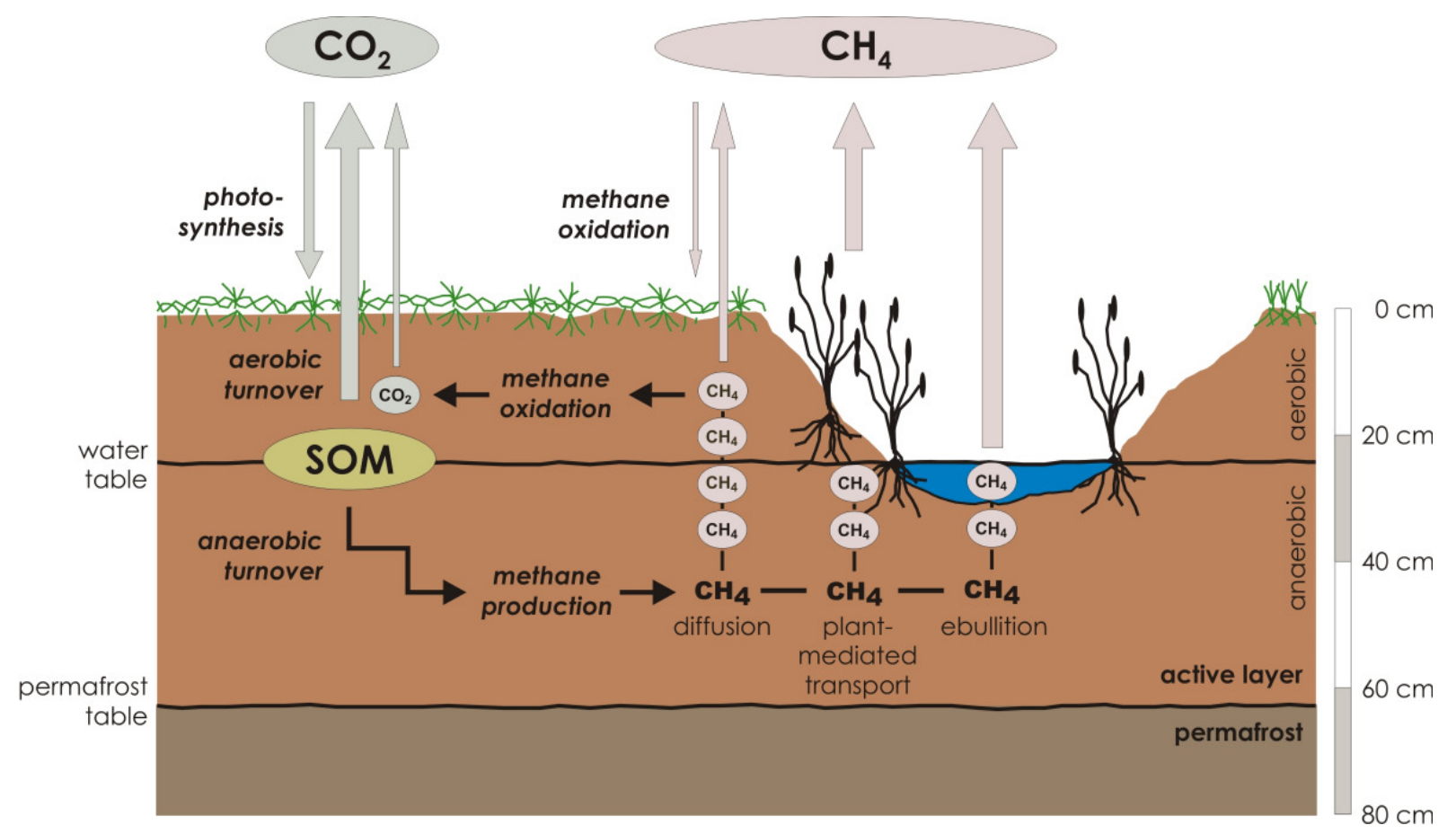

Fig. 15.2: The carbon cycle in permafrost soils: Permafrost soils can be both a source and a sink for $\mathrm{CO}_{2}$ and $\mathrm{CH}_{4}$. Under aerobic conditions soil organic matter (SOM) is respired to $\mathrm{CO}_{2}$, whereas under anaerobic conditions SOM is decomposed via a sequence of microbial processes to $\mathrm{CH}_{4}$. Methane fluxes from anaerobic soil horizons to the atmosphere results from diffusion (slow), ebullition (fast), and through plant-mediated transport (bypassing the oxic soil layer). Therefore, the way of transport determines the amount of methane that is re-oxidized by microorganisms in aerobic soil horizons. Photosynthesis poses as an important sink for $\mathrm{CO}_{2}$ in permafrost environments. Thereby biomass is produced. In contrast, the consumption of atmospheric methane (negative methane flux) in the upper surface layer of the soils plays only a minor role for the methane budget. The thickness of the arrows reflects the importance of the above processes.

Nervertheless, the quantity of organic matter provides no information on its quality. This, however, determines the availability of organic compounds as energy and carbon sources for microorganisms (Hogg 1993; Bergman et al. 2000; see also Chapter 17). For this purpose the humification index (HIX, dimensionless) for instance, is a criterion for organic matter quality and can, therefore, give suitable 
information with regard to microbial metabolism (Zsolnay 2003). It was demonstrated that the availability of organic carbon in permafrost soils decreased with increasing HIX (Wagner et al. 2005). It was further shown that the HIX increased continuously with depth in Holocene permafrost sediments (Wagner et al. 2007). This indicates that the organic carbon is less available for microorganisms with increasing depth because of the higher degree of humification. Therefore, beside the quantity also the quality of soil organic matter should be taken into account in consideration of permafrost environments as a huge carbon reservoir.

Wherever oxygen is present in permafrost habitats (upper oxic soil horizons, rhizosphere), methane can be oxidized to carbon dioxide by aerobic methane oxidizing bacteria (see Chapter 15.3.2). Between $76 \%$ and up to more than $90 \%$ of the methane produced in wetlands was oxidized by these specialists before reaching the atmosphere (Roslev and King 1996; Le Mer and Roger 2001). Hence, the biological oxidation of methane represents the major sink for methane in arctic permafrost environments.

Vegetation is another important factor occupying a central position for microbial processes and the transport of methane. Plants can have both enhancing and attenuating effects on methane emission. Through the aerenchyma of vascular plants, oxygen is transported from the atmosphere to the rhizosphere, thus stimulating methane oxidation in otherwise anoxic soil horizons (Van der Nat and Middelburg 1998; Popp et al. 2000). In opposite direction, the aerenchyma is a major pathway for methane transport from the anoxic horizons to the atmosphere, bypassing the oxic/anoxic interface in the soil, where methane oxidation is most prominent. It was shown that up to $68 \%$ of the total methane release from wet permafrost soils is transported through sedges like Carex aquatilis (Kutzbach et al. 2003). Furthermore, the vegetation provides the substrates for methanogenesis such as decaying plant material and fresh root exudates (Whiting and Chanton 1992; Joabsson et al. 1999).

\subsection{Microbial Communities of the Methane Cycle}

The biological formation and consumption of methane are carried out by very specialized microorganisms, methanogens and methanotrophs. Thereby, methane production results solely from the activity of members of the kingdom Euryarchaeota, the so called methanogenic archaea (methanogens). The group of microorganisms capable to consume methane (methanotrophs), however, is more complex comprising obligate aerobic members of the phyla Proteobacteria (Bowman et al. 1999), and Verrucomicrobiaea (Dunfield et al. 2007; Pol et al. 2007), as well as anaerobically methane oxidizing archaea in marine habitats (e.g. Boetius et al. 2000), and bacteria of a yet unknown phylum carrying out methane oxidation in the 
presence of very high nitrate and methane concentration in freshwater habitats (Raghoebarsing et al. 2006). The dominant methane consuming microorganisms in permafrost soils are those of the Proteobacteria phylum. Because of the pronounced distribution of methanogenic archaea and methanotrophic Proteobacteria in Arctic permafrost soils (reviewed by Wagner 2008, Fig. 15.3) and their significance for the global methane budget, these two groups are of particular attention in this review.

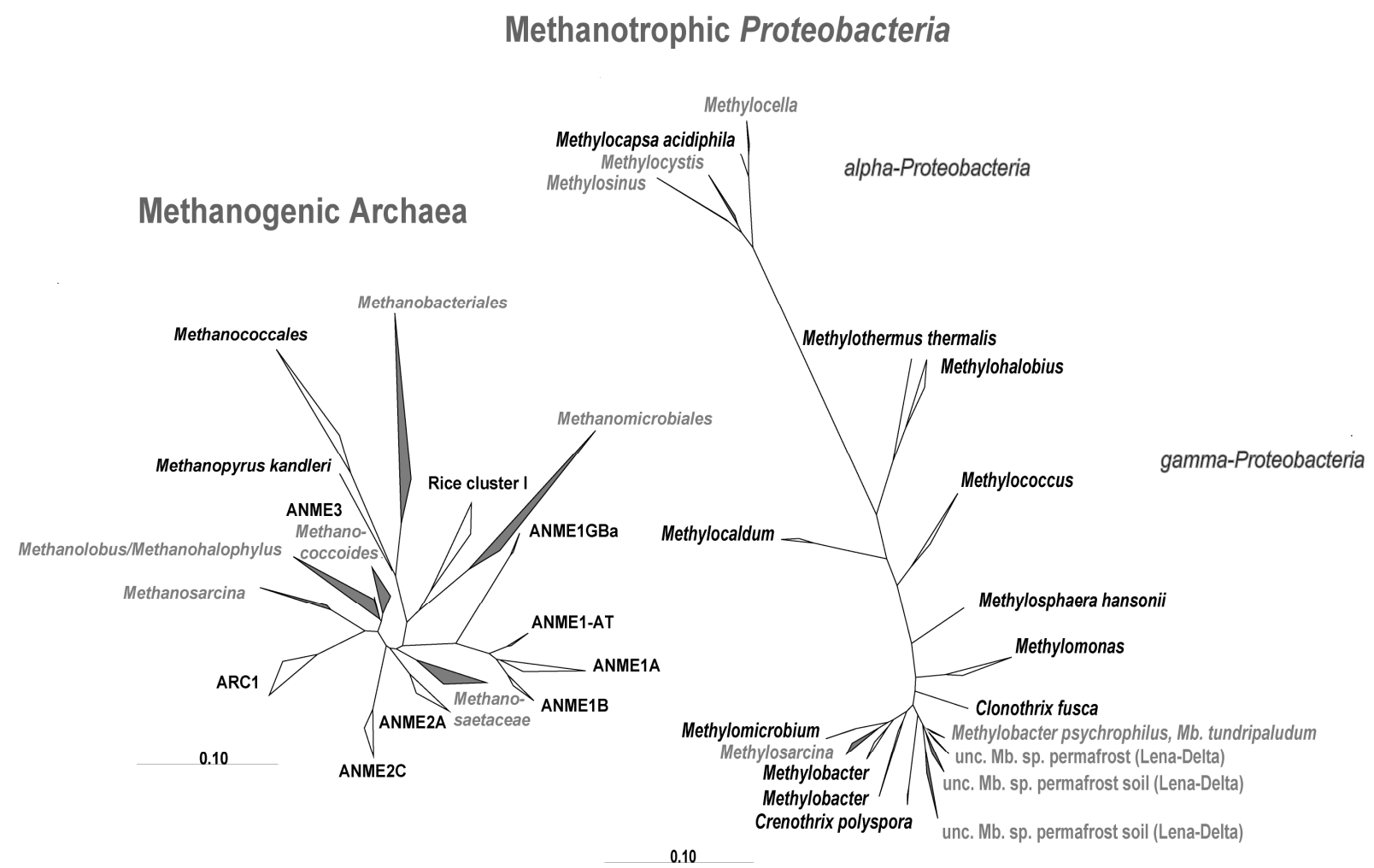

Fig. 15.3 Phylogenetic relation (based on 16S rRNA gene sequences) of methanogenic archaea and aerobic methanotrophic bacteria. Grey squares illustrate groups including sequences from arctic tundra environments. Trees represent maximum likelihood trees using the PhyML algorithm (Guindon and Gascuel, 2003) and the ARB software package.

\subsubsection{Methanogenic Archaea}

Methanogenic archaea represent a small group of strictly anaerobic microorganisms (Hedderich and Whitman 2006). They can be found either in temperate habitats like paddy fields (Grosskopf et al. 1998), lakes (Jurgens et al. 2000; Keough et al. 2003), freshwater sediments (Chan et al., 2005), in the gastrointestinal tract of animals (Lin et al. 1997), or in extreme habitats such as hydrothermal vents (Jeanthon et al. 1999), hypersaline habitats (Mathrani \& Boone 1995) or permafrost soils and 
sediments (Rivkina et al. 1998; Kobabe et al. 2004). In cold environments, two main pathways of energy-metabolism dominate: (i) the reduction of $\mathrm{CO}_{2}$ to $\mathrm{CH}_{4}$ using $\mathrm{H}_{2}$ as a reductant and (ii) the fermentation of acetate to $\mathrm{CH}_{4}$ and $\mathrm{CO}_{2}$ (Conrad 2005). However, only a few psychrophilic (cold-adapted) strains of methanogenic archaea have been described so far (Simankova et al. 2003; Cavicchioli 2006).

Although permafrost environments are characterized by extreme climate conditions, it was recently shown that the abundance and composition of the methanogenic population is similar to that of communities of comparable temperate soil ecosystems (Wagner et al. 2005). The highest cell counts of methanogenic archaea were detected in the active layer of permafrost, with numbers of up to $3 \mathrm{x}$ $10^{8}$ cells g $^{-1}$ soil (Kobabe et al. 2004). Methanogenic archaea represented between $0.5 \%$ and $22.4 \%$ of the total cell counts. Phylogenetic analyses revealed a great diversity of methanogens in the active layer, with species belonging to the families Methanobacteriaceae, Methanomicrobiaceae, Methanosarcinaceae, and Methanosaetaceae (Høj et al. 2005; Metje and Frenzel 2007; Ganzert et al. 2007; Fig. 15.3). Other sequences detected were affiliated to the euryarchaeotal Rice Cluster II and V (Hales et al. 1996; Grosskopf et al. 1998; Ramakrishnan et al. 2001) as well as to the Group I.3b of the uncultured Crenarchaeota (non-methanogenic archaea; Ochsenreiter et al. 2003). Environmental sequences from the Laptev Sea coast form four specific permafrost clusters (Ganzert et al. 2007). Permafrost Cluster I was recovered mainly from cold horizons (with temperatures of less than $4^{\circ} \mathrm{C}$ ) of the active layer and was related to Methanosarcinacea. Permafrost Clusters II and III were related to Methanomicrobiales and Permafrost Cluster IV was related to Rice Cluster II. It was hypothesized that these clusters comprise methanogenic archaea with a specific physiological potential to survive under harsh environmental conditions. The phylogenetic affiliation of the sequences recovered in this study indicated that both hydrogenotrophic and acetoclastic methanogenesis exist in permafrost soils. Recent studies on perennially frozen permafrost deposits from the Lena Delta (Siberia) revealed significant amounts of methane which could be attributed to in situ activity of methanogenic archaea (Wagner et al. 2007). Another study on frozen ground on Ellesmere Island reported an archaeal community composed of $61 \%$ Euryarchaeota (methane producing archaea) and $39 \%$ Crenarchaeota, suggesting the presence of a diverse archaeal population also in the perennially frozen sediments (Steven et al. 2007).

Methanosarcina spec. SMA-21, which is closely related to Methanosarcina mazei, was recently isolated from a Siberian permafrost soil in the Lena Delta. The organism grows well at $28^{\circ} \mathrm{C}$ and slowly at low temperatures $\left(4^{\circ} \mathrm{C}\right.$ and $\left.10^{\circ} \mathrm{C}\right)$ with $\mathrm{H}_{2} / \mathrm{CO}_{2}(80: 20, \mathrm{v} / \mathrm{v}$, pressurised at $150 \mathrm{kPa})$ as substrate. The cells grow as cocci, with a diameter of 1-2 $\mu \mathrm{m}$. Cell aggregates were regularly observed (Fig. $15.4 \mathrm{a}$ ). Methanosarcina SMA-21 is characterized by an extreme tolerance to very low temperatures $\left(-78.5^{\circ} \mathrm{C}\right.$ ), high salinity (up to $6 \mathrm{M}$ ), starvation, desiccation and oxygen 
exposure (Morozova and Wagner 2007). Furthermore, this archaeon survived for three weeks under simulated thermo-physical Martian conditions (Morozova et al. 2007; see also Chapter 22).
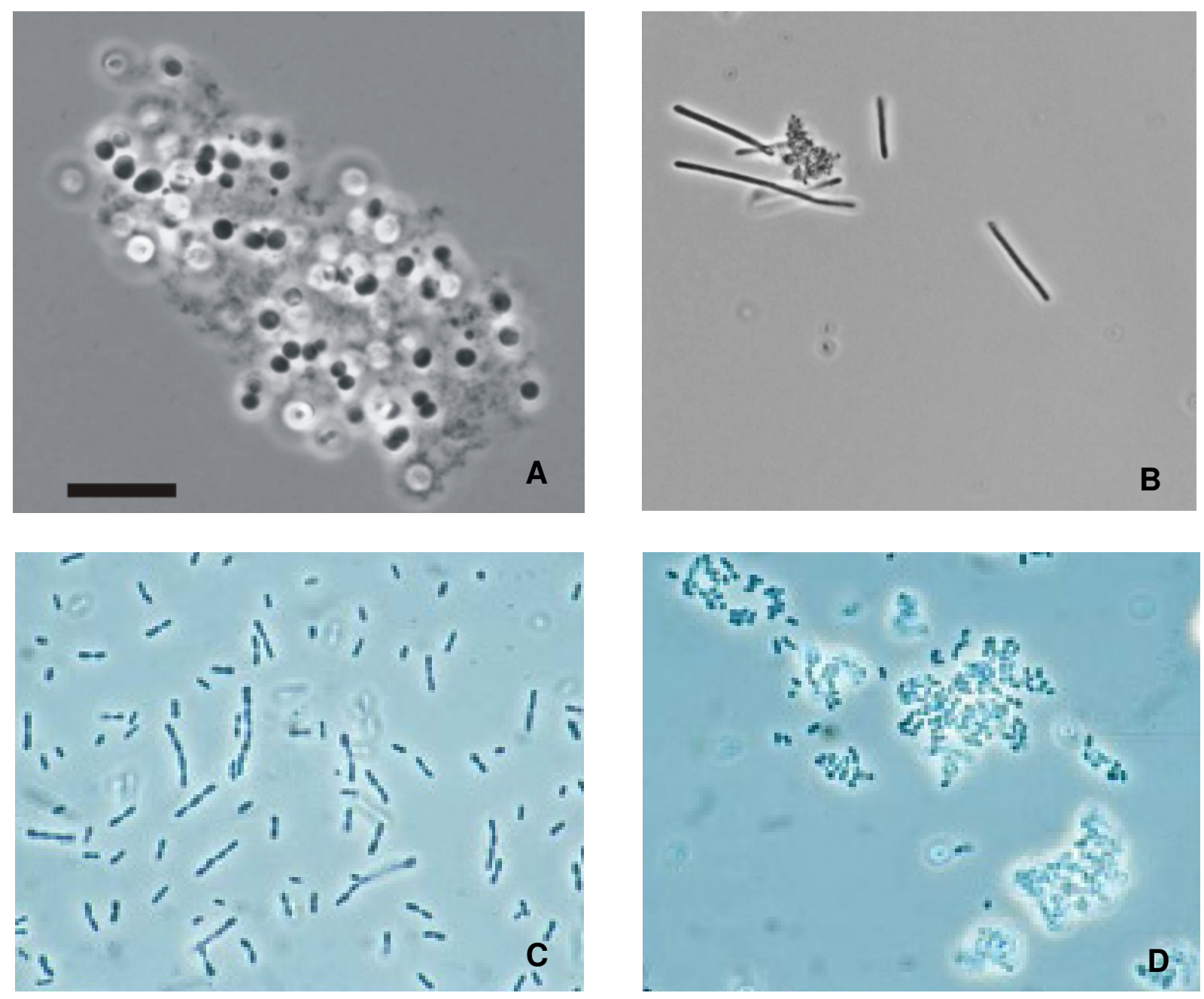

Fig. 15.4 Methane-cycling microorganisms isolated from permafrost environments: (A) Methanosarcina sp. SMA-21 (D. Wagner and D. Morozova, AWI; bar: 10 $\mu \mathrm{m})$; (B) permafrost strain SMA-23 (D. Wagner and D. Morozova, AWI); (c) Methylobacter tundripaludum (Wartiainen et al. 2006a); (d) Methylocystis rosea (Wartiainen et al. 2006b)

Methanogenic activity was observed at low in situ temperatures with rates of up to $39 \mathrm{nmol} \mathrm{CH}_{4} \mathrm{~h}^{-1} \mathrm{~g}^{-1}$ soil in the active layer of permafrost (Wagner et al. 2003; Høj et al. 2005; Metje and Frenzel 2007). The highest activities were thereby measured in the coldest zones of the profiles. Furthermore, it could be shown that methane production is rather limited by the quality of soil organic carbon than by the in situ temperature (Wagner et al. 2005; Ganzert et al. 2007). Another important 
factor affecting methanogenic communities in permafrost soils is the water regime. Along a natural soil moisture gradient, changes in archaeal community composition were observed, which suggest that the differences in these communities were responsible for the large-scale variations in methane emissions observed with changes in soil hydrology (Høj et al. 2006).

\subsubsection{Methane Oxidizing Proteobacteria}

Based on their function as the major sink for methane in arctic permafrost affected wetlands and tundra, methane oxidizing Proteobacteria are also of importance for the greenhouse gas (GHG) budget of these environments.

Methane oxidizing Proteobacteria represent a subset of methylotrophic bacteria. Through the activity of their specific enzyme, methane monooxygenase, they are specialized to utilize methane as single carbon and energy source (Hanson and Hanson, 1996). The group of methane oxidizing Proteobacteria comprises the three families Methylococcaceae, Methylocystaceae, and Beijerinckiaceae (Bowman 1999; Dedysh et al. 2000; 2001; 2002; 2004). The only exception is Crenothrix polyspora, a filamentous, sheathed microorganism recently discovered to be methanotrophic (Stoecker et al. 2006). Methylococcaceae include the genera Methylobacter, Methylomonas, Methylomicrobium, Methylosarcina, Methylosphaera, Methylohalobius, Methylosoma, Methylothermus, Methylococcus, and Methylocaldum (Hanson and Hanson 1996; Bowman et al. 1997; Wise et al. 2001; Heyer et al. 2005; Tsubota et al. 2005; Rahalkar et al. 2007). They belong to the gamma-subdivision of the Proteobacteria phylum and are termed type I methanotrophs, except for the last two, which are also known as type $X$ methanotrophs. The families Methylocystaceae, and Beijerinckiaceae include the genera Methylosinus, Methylocystis, Methylocella, and Methylocapsa (Hanson and Hanson 1996; Bowman et al. 1999; Dedysh et al. 2000; 2001; 2002; 2004). Members of the Methylocystaceae and Beijerinckiaceae are termed type II methanotrophs and belong to the alpha-subdivision of the Proteobacteria phylum. Except for their phylogeny, type I and type II methanotrophs can also be distinguished by their carbon assimilation pathway, the structure of their intracytoplasmic membranes, their resting stages, $\mathrm{G}+\mathrm{C}$-content, the constitution of their methane monooxygenase, and by their major phospholipid fatty acids (PLFAs).

Several studies revealed that methanotrophs are abundant and active also under very harsh environmental conditions of cold environments (review by Trotsenko and Khmelenina 2005). Viable methane oxidizers were even detected in deep Siberian permafrost sediments with ages of 1000-100,000 years (Khmelenina et al. 2001). Numerous psychrophilic and psychrotrophic methanotrophs, primarily affiliated to the type I group, are known such as Methylobacter psychrophilus, isolated from Siberian tundra (Omelchenko et al. 1996), Methylobacter 
tundripaludum, isolated from Arctic wetland soils (Fig. 15.4, Wartiainen et al. 2006a), Methylosphaera hansonii, isolated from Antarctic, marine salinity, meromictic lakes (Bowman et al. 1997), and Methylomonas scandinavica, isolated from deep igneous rock ground water (Kaluzhnaya et al. 1999). Type I methanotrophs were also recovered to dominate in arctic permafrost affected soils (Wartiainen et al. 2003; Wagner et al. 2005; Liebner and Wagner 2007). Within the type II group, Methylocystis rosea, isolated from an Arctic wetland soil (Fig. 15.4, Wartiainen et al. 2006b), and representatives of the acidophilic genera Methylocella and Methylocapsa were reported to be psychrotrophs (Dedysh et al. 2002; 2004).

Methane oxidizing Proteobacteria were shown to be highly abundant in permafrost soils of the Lena Delta, Siberia, with cell numbers ranging between $3 \mathrm{x}$ $10^{6}$ and $1 \times 10^{8}$ cells $^{-1}$ soil and contributing up to $10 \%$ to the total number of microbial cells (Liebner and Wagner 2007). In the same area, specific clusters of methane oxidizing Proteobacteria closely related to Methylobacter psychrophilus and to Methylobacter tundripaludum were detected indicating a micro-diverse community on the species level (Liebner et al. 2008). Also, highly divergent functional gene sequences of these methanotrophs were found in soils of the high Canadian Arctic (Pacheco-Oliver et al. 2002). In contrast, the diversity of methane oxidizing Proteobacteria in an arctic wetland on the island of Svalbard was observed to be restricted to only two genera (Wartiainen et al. 2003), whereas most methanotrophic Proteobacteria were detected in a Russian sub-arctic tundra (Kaluzhnaya et al. 2002). Still, diversity and composition of methane oxidizing bacteria in permafrost soils are only poorly explored. Also, it remains unknown whether psychrophilic or cold-adapted mesophilic methantrophs are responsible for methane oxidation at low and subzero temperatures in permafrost sediments (Trotsenko and Khmelenina 2005). A recent study, though, observed a shift between a mesophilic methanotrophic community near the surface and a psychrophilic methanotrophic community near the permafrost table of Siberian permafrost soils (Liebner and Wagner 2007). This indicates that depending on the environmental conditions both mesophilic as well as psychrophilic methanotrophs are active in Siberian permafrost soils.

\subsection{Methane-cycling Communities under Global Climate Change}

Arctic surface temperatures on average increased to a greater extent than those of the rest of the earth (IPCC 2001), causing a particular susceptibility of arctic permafrost to degradation. Global warming could degrade $25 \%$ of the total permafrost area by 2100 (Anisimov et al. 1999). Also, Nelson et al. (2001) predicted a high potential of large areas of Siberian permafrost to be degraded, which would primarily lead to a thickening of the seasonally thawed layer (active layer). In the period 1956-1990, the active layer in Russian permafrost already increased by on 
average $20 \mathrm{~cm}$ (IPCC 2007). By the end of the $21^{\text {st }}$ century, an increase of mean annual ground temperature by up to $6{ }^{\circ} \mathrm{C}$ and of active layer depth by up to $2 \mathrm{~m}$ is expected for East Siberia (Stendel et al. 2007). Although the estimated size of the carbon pool in Arctic permafrost affected tundra varies between 190 and, in more recent studies, approximately $900 \mathrm{Gt}$, it accounts for at least $13-15 \%$ of the global carbon pool in soils (Post et al. 1982; Zimov et al. 2006). Thawing of $10 \%$ of the total Siberian permafrost carbon reservoir was suggested to initially release about $1 \mathrm{Pg}$ carbon followed by respiration of about $40 \mathrm{Pg}$ carbon to the atmosphere over a period of four decades (Dutta et al. 2006). Model calculations suggest that methane currently emitted from Arctic permafrost environments may enhance the greenhouse effect with a portion of approx. $20 \%$ (Wuebbles and Hayhoe 2002). Palaeoclimate reconstruction combined with biogeochemical biomarker analysis, for example, revealed an increase in production and release of methane from the terrestrial biosphere during the Palaeocene-Eocene thermal maximum, a period of intense global warming 55 million years ago (Pancost et al. 2007). It was also shown that an increase of the permafrost temperature in Holocene permafrost deposits of northern Siberia would lead to substantial rise in microbiologically produced methane (Wagner et al. 2007). Serious concerns are thus associated with the potential impact that thawing permafrost may have on the global climate system through release of greenhouse gases (Friborg et al. 2003; Christensen et al. 2004; Wagner et al. 2007). Methane flux models do indeed predict increasing methane emissions in latitudes above $60^{\circ} \mathrm{N}$ by $19-25 \%$ (Cao et al. 1998; Walter et al. 2001; Zhuang et al. 2004). These estimates are challenged, though, by other studies suggesting that increasing methane fluxes from Russian permafrost regions will change atmospheric methane concentrations by only $0.04 \mathrm{ppm}(2.3 \%)$ leading to $0.012{ }^{\circ} \mathrm{C}$ temperature rise globally (Anisimov 2007).

Models on modern methane emissions from arctic wetlands determine methane production and methane oxidation rates primarily as functions of substrate availability, substrate concentration, and temperature as well as indirectly of water table and thaw depth (Walter et al. 2001; Zhuang et al. 2004; Anisimov 2007). Changes of these parameters will consequently lead to short-term alterations of methane production and methane oxidation rates. Whether, however, the currently observed global climate change will effectively alter modern methane fluxes from arctic permafrost affected wetlands will particularly depend on its long-term impact on the methane cycling communities and their ability to adapt to the new environmental conditions. This ability is very likely dependant on the level of specialisation and diversity of the indigenous microbial communities. It was observed that an increase of temperature and precipitation altered the community structure and relative abundance of methane oxidizers in rice, forest and grassland soils (Horz et al. 2005; Mohanty et al. 2007). Also, the overall relative abundance and diversity of methanogenic archaea in a high Arctic peat from Spitsbergen increased with 
increasing temperature, in accordance with a strong stimulation of methane production rates (Høj et al. 2008). In contrast, the population structure of methanogenic archaea in a permafrost affected peat in Siberia remained constant over a wide temperature range (Metje and Frenzel 2007). Also, a psychrophilic and little diverse methanotrophic community as detected near the permafrost table of Siberian polygonal tundra soils (Liebner and Wagner 2007; Liebner et al. 2008) will likely require more time for resilience than the diverse mesophilic-psychrotolerant methanogenic community detected in permafrost soils of the same region (Ganzert et al. 2006).

There is, however, a lack of experimental research investigating the long-term effect of simulated climate change on the methane cycling communities in permafrost soils, which would be essential to prove or disprove the previously mentioned assumptions. Also, an account of the entire plant-microbe-animal system and the interactions between metabolic networks, which are important for methanogenesis is missing in modern methane flux models (Panikov 1999). Due to this poor knowledge it is worthy to consider microbial communities in the scope of global climate change in general. Simulating the affects of warming on the competition between psychrophilic and mesophilic sub-populations of Pseudomonas, for example, displayed a high degree of stability of this artificial community (Panikov 1999). Psychrophiles dominated the bacterial community under cold conditions, and an increase in temperature by $5{ }^{\circ} \mathrm{C}$ did not affect their domination. Further warming of another $5{ }^{\circ} \mathrm{C}$ resulted in a rapid $50 \%$ substitution of psychrophiles by mesophiles over two years finally reaching a stable coexistence between the two subpopulations. In the same model, the main effect of rising temperatures on the carbon balance of the ecosystem was a considerable activation of organic matter decomposition due to higher production of hydrolytic enzymes. Experimental setups revealed a rather low direct impact of rising temperatures on the decomposition of soil organic matter but rather attributed increased decomposition rates most strongly to be due to changes in local substrate characteristics and vegetation type (Zhang et al. 2005; Bokhorst et al. 2007). Still, a warming induced shift in the microbial community structure was again observed at least in the first study.

To summarize, there is an urgent need for modelling the response of methane cycling communities in permafrost regions to global climate change on the one hand and to validate these models by empirical data on the other hand. This is not only due to the importance of these communities for the atmospheric methane budget and thus for the global climate. It is also inevitable given the close connection between physiology and function of these communities in permafrost soils that allows for a general understanding of how important is the stability of microbial communities for the GHG budget of arctic permafrost affected wetlands. 


\subsection{Conclusions and Future Perspectives}

Permafrost soils and sediments are unique systems in the context of biogeochemical cycling of carbon, particularly due to the enormous amount of organic carbon stored in these environments. Recent studies demonstrate the close relationship between apparent methane fluxes and the modes and intensities of microbiological processes of methane production and oxidation in permafrost ecosystems. Methane producing and consuming microorganisms are widespread, highly active and abundant in permafrost soils, despite the harsh environmental conditions they are exposed to. The permafrost environment forces an adaptation of the methane cycling communities to low temperature conditions often yealding species, which have not been detected in temperate ecosystems so far. In addition to soil characteristics and climate conditions, the activity and physiology of these well adapted microbial communities dictate trace gas fluxes in permafrost soils. The future development of permafrost environments as a source of methane, therefore, primarily depends on the response of the methanogenic and methanotrophic microorganisms to a changing environment.

Anticipating this response, however, is difficult as the sensitivity of microbial communities to permafrost degradation is completely unknown. At first, there is lack of experimental and theoretic studies on what determines microbial stability in general and in particular in permafrost environments. At second, the consequences of thawing permafrost on hydrology and morphology that indirectly influence microbial communities and its activity are very difficult to predict.

International projects such as ACD (Arctic Coastal Dynamics) and CALM (Circumpolar Active Layer Monitoring), which examine the impact of global warming on permafrost environments should thus be linked more closely to microbiological process studies and biodiversity research. Microbial parameters important for the assessment of carbon turnover (e.g. cell numbers, activities, biodiversity and stability of microbial communities) should be analysed at observation areas in the Arctic, where long-term monitoring programs are undertaken. The evaluation of microbial ecology and its correlation to climatic and geochemical data represent the basis for an understanding of the role of permafrost soils in the global system, in particular in terms of feedback mechanisms related to fluxes of material and greenhouse gases in the scope of a warming Earth.

\section{References}

Anisimov OA, Nelson FE, and Pavlov AV (1999) Predictive scenarios of permafrost development under conditions of global climate change in the XXI century. Earth Cryology 3: 15-25 
Anisimov OA (2007) Potential feedback of thawing permafrost to the global climate system through methane emission. Environ Res Lett 2: 045016 (7pp)

Aselmann I and Crutzen J (1989) Global distribution of natural freshwater wetlands and rice paddies, their net primary productivity, seasonality and possible methane emissions. J Atmospheric Chem 8: 307-358

Bartlett KB, Crill PM, Sass RL, Harriss RC and Dise NB (1992) Methane emissions from tundra environments in the Yukon-Kuskokwim Delta, Alaska. Journal of Geophysical Research 97 (D15): 16645-16660

Bergman I, Klarqvist M and Nilsson M (2000) Seasonal variation in rates of methane production from peat of various botanical origins: effects of temperature and substrate quality. FEMS Microbiology Ecology 33: 181-189

Boetius A, Ravenschlag K, Schubert CJ, Rickert D, Widdel F, Gieseke, A, Amann R, Jørgensen BB, Witte $U$, and Pfannuche $O$ (2000) A marine microbial consortium apparently mediating anaerobic oxidation of methane. Nature 407: 623-626

Bokhorst S, Huiskes A, Convey P, and Aerts R (2007) Climate change effects on organic matter decomposition rates in ecosystems from the Maritime Antarctic and Falkland Islands. Global Change Biol 13: 2642-2653

Bowman JP, McCammon SA, and Skerratt MG (1997) Methylosphaera hansonii gen. nov., sp. nov., a psychrophilic, group I methanotroph from Antarctic, marine salinity, meromictic lakes. Microbiology 143: 1451-1459

Bowman JP (1999) The Methanotrophs - The families Methylococcaceae and Methylocystaceae In: The Prokaryotes. Dworkin M (ed), Springer, New York

Bubier JA, Moore TR, Bellisario L and Comer NT (1995) Ecological controls on methane emissions from a northern peatland complex in the zone of discontinous permafrost, Manitoba, Canada. Global Biogeochemical Cycles 9: 455-470

Cao MK, Marshall S and Gregson K (1996) Global carbon exchange and methane emissions from natural wetlands: Application of a process-based model, Journal of Geophysical 101(D9): 14399-14414

Cao MK, Gregson K, and Marshall S (1998) Global methane emission from wetlands and its sensitivity to climate change. Atmos Environ 32: 3293-3299

Cavicchioli R (2006) Cold-adapted archaea. Nature 4: 331-343

Chan OC, Claus P, Casper P, Ulrich A, Lueders T and Conrad R (2005) Vertical distribution of the methanogenic archaeal community in Lake Dagow sediment. Environ Microbiol 7: 1139-1149

Christensen TR, Jonasson S, Callaghan TV and Havström M (1995) Spatial variation in high-latitude methane flux along a transect across Siberian and Eurasian tundra environments, J Geophys Res 100: 21035-21045

Christensen TR, Friborg T, Sommerkorn M, Kaplan J, Illeris L, Soegaard H, Nordstroem $C$ and Jonasson S (2000) Trace gas exchange in a high-arctic valley: 1. Variations in $\mathrm{CO}_{2}$ and $\mathrm{CH}_{4}$ flux between tundra vegetation types. Global Biogeochemical Cycle 14: 701-713

Christensen TR, Johansson TR, Akerman HJ, Mastepanov M, Malmer N, Friborg T, Crill P, and Svensson BH (2004) Thawing sub-arctic permafrost: effects on vegetation and methane emissions. Geophys Res Lett 30: L04501

Conrad R (2005) Quantification of methanogenic pathways using stable carbonisotopic signatures: a review and a proposal. Organ Geochem 36: 739752 
Corradi C, Kolle O, Walter K, Zimov SA and Schulze ED (2005) Carbon dioxide and methane exchange of a north-east Siberian tussock tundra, Global Change Biology 11, 1910-1925

Dedysh SN, Liesack W, Khmelenina VN, Suzina NE, Trotsenko YA, Semrau JD, Bares AM, Panikov NS, and Tiedje JM (2000) Methylocella palustris gen. nov., sp. nov., a new methane oxidizing acidophilic bacterium from peat bogs, representing a novel subtype of serine-pathway methanotrophs. Int J Syst Evol Microbiol 50: 955-969

Dedysh SN, Horz HP, Dunfield PE, and Liesack W (2001) A novel pmoA lineage represented by the acidophilic methanotrophic bacterium Methylocapsa acidiphila B2. Arch Microbiol 177: 117-121

Dedysh SN, Khmelenina VN, Suzina NE, Trotsenko YA, Semrau JD, Liesack W, and Tiedje JM (2002) Methylocapsa acidiphila gen. nov., sp. nov., a novel methane-oxidizing and dinitrogenfixing acidophilic bacterium from Sphagnum bog. Int J Syst Evol Microbiol 52: 251-261

Dedysh SN, Berestovskaya YY, Vasilieva LV, Belova SE, Khmelenina VN, Suzina NE, Trotsenko YA, Liesack W, and Zavarzin GA (2004) Methylocella tundrae sp. nov., a novel methanotrophic bacterium from acidic tundra peatlands. Intern J Syst Evol Microbiol 54: 151-156

Dunfield PF, Yuryev A, Senin P, Smirnova AV, Stott MS, Hou S, Ly B, Saw JH, Zhou Z, Ren Y, Wang J, Mountain BW, Crowe MA, Weatherby TM, Bodelier PLE, Liesack W, Feng L, Wang L, and Alam M (2007) Methane oxidation by an extremely acidophilic bacterium of the phylum Verrucomicrobia. Nature 450: 879-882

Dutta K, Schuur EAG, Neff JC, and Zimov SA (2006) Potential carbon release from permafrost soils of Northeastern Siberia. Global Change Biology 12: 23362351

Ehhalt DH and Schmidt U (1978) Sources and sinks of atmospheric methane. Pure and Applied Geophysics 116: 452-464

Frenzel P and Karofeld E (2000) $\mathrm{CH} 4$ emission from a hollow-ridge complex in a raised bog: the role of $\mathrm{CH} 4$ production and oxidation. Biogeochemistry 51: 91112

Friborg T, Soegaard H, Christensen TR, Lloyd CR, and Panikov N (2003) Siberian wetlands: where a sink is a source. Geophys Res Lett 30: 2129

Fung I, John J, Lerner J, Matthews E, Prather M, Steele LP and Fraser PJ (1991) Three-dimensional model synthesis of the global methane cycle. J Geophysical Res 96: 13033-13065

Ganzert L, Jurgens G, Münster U, and Wagner D (2007) Methanogenic communities in permafrost-affected soils of the Laptev Sea coast, Siberian Arctic, characterized by $16 \mathrm{~S}$ rRNA gene fingerprints. FEMS Microbiol Ecol 59: 476488

Gorham E (1991) Northern peatlands role in the carbon cycle and probable responses to climatic warming. Ecological Applications 1: 182-195

Grosskopf R, Stubner S and Liesack W (1998) Novel euryarchaeotal lineages detected on rice roots and in the anoxic bulk soil of flooded rice microcosms. Appl Environ Microbiol 64: 4983-4989

Guindon S and Gascuel O (2003) A simple, fast, and accurate algorithm to estimate large phylogenies by maximum likelihood. Syst Biol 52: 696-704

Hales BA, Edwards C, Ritchie DA, Hall G, Pickup RW and Saunders JR (1996) Isolation and identification of methanogen-specific DNA from blanket bog peat 
by PCR amplification and sequence analysis. Appl Environ Microbiol 62: 668675

Hanson RS and Hanson TE (1996) Methanotrophic Bacteria. Microbiological Reviews 60: 439-471

Hedderich R and Whitman W (2006) Physiology and biochemistry of the methaneproducing archaea. In: Dworkin M, Falkow S, Rosenberg E, Schleifer K-H, Stackebrandt E (eds.) Prokaryotes, vol 2, Springer, New York, pp 1050-1079

Heyer J, Berger U, Hardt M, and Dunfield PF (2005) Methylohalobius crimeensis gen. nov., sp. nov., a moderately halophilic, methanotrophic bacterium isolated from hypersaline lakes of Crimea. International Journal of Systematic and Evolutionary Microbiology 55: 1817-1826

Hogg EH (1993) Decay potential of hummock and hollow Sphagnum peats at different depths in a Swedish raised bog. Oikos 66: 269-278

Horz HP, Rich V, Avrahami S, Bohannan BJM (2005) Methane-Oxidizing Bacteria in a California Upland Grassland Soil: Diversity and Response to Stimulated Global Change. Appl Environ Microbiol 71: 2642-2652

Høj L, Olsen RA and Torsvik VL (2005) Archaeal communities in High Arctic wetlands at Spitsbergen, Norway $\left(78^{\circ} \mathrm{N}\right)$ as characterised by $16 \mathrm{~S}$ rRNA gene fingerprinting. FEMS Microbiol Ecol 53: 89-101

Høj L, Rusten M, Haugen LE, Olsen RA and Torsvik VL (2006) Effects of water regime on archaeal community composition in Arctic soils. Environ. Microbiol 8: 984-996

Høy L, Olsen RA, and Torsvik VL (2008) Effects of temperature on the diversity and community structure of known methanogenic groups and other archaea in high Arctic peat. ISME J 2: 37-48

IPCC (2001) Climate Change 2001: The Scientific Basis. URL: http://www.grida.no/climate/ipcc tar/wg1/index.htm

IPCC (2007) Climate Change 2007: Contribution of Working Group I to the Fourth Assessment Report of the Intergovernmental Panel on Climate Change, The Physical Basis of Climate Change: http://www.ipcc-wg2.org/index.html

Jeanthon C, L'Haridon S, Pradel N and Prieur D (1999) Rapid identification of hyperthermophilic methanococci isolated from deep-sea hydrothermal vents. Int J Syst Bacteriol 49: 591-594

Joabsson A, Christensen TR and Wallén B (1999) Influence of vascular plant photosynthetic rate on $\mathrm{CH}_{4}$ emission from peat monoliths from southern boreal Sweden. Polar Res 18: 215-220

Joabsson A and Christensen TR (2001) Methane emissions from wetlands and their relationship with vascular plants: an Arctic example. Global Change Biology 7: 919-932

Jurgens G, Glöckner FO, Amann R, Saano A, Montonen L, Likolammi M and Münster $U$ (2000) Identification of novel Archaea in bacterioplancton of a boreal forest lake by phylogenetic analysis and fluorescence in situ hybridisation. FEMS Microbiol Ecol 34: 45-56

Kaluzhnaya MG, Khmelenina VN, Kotelnikova S, Holmquist L, Pedersen K, and Trotsenko YA (1999) Methylomonas scandinavica gen. nov., sp. nov., a new methanotrophic psychrotrophic bacterium isolated from deep igneous rock ground water of Sweden. System Appl Microbiol 22: 565-572

Kaluzhnaya MG, Makutina VA, Rusakova TG, Nikitin DV, Khmelenina VN, Dmitriev VV, and Trotsenko YA (2002) Methanotrophic communities in the soils of the Russian northern taiga and subarctic tundra. Microbiology 71: 223-227 
Keough BP, Schmidt TM and Hicks RE (2003) Archaeal nucleic acids in picoplankton from great lakes on three continents. Microbial Ecol 46: 238-248

Khmelenina VN, Makutina VA, Kaluzhnaya MG, Rivkina EM, Gilichinsky DA, and Trotsenko YA (2001) Discovery of viable methanotrophic bacteria in permafrost sediments of northeast Siberia. Dokl Biol Sci 384: 235-237

Kobabe S, Wagner D and Pfeiffer EM (2004) Characterization of microbial community composition of a Siberian tundra soil by fluorescence in situ hybridization. FEMS Microbiol Ecol 50: 13-23

Kutzbach L, Wagner D and Pfeiffer EM (2004) Effect of microrelief and vegetation on methane emission from wet polygonal tundra, Lena Delta, Northern Siberia. Biogeochemistry 69: 341-362

Kutzbach L, Wille C, Pfeiffer EM (2007) The exchange of carbon dioxide between wet arctic tundra and the atmosphere at the Lena River Delta, Northern Siberia. Biogeosciences 4: 869-890

Le Mer J, and Roger P (2001) Production, oxidation, emission and consumption of methane by soils: A review. Eur J Soi Bio 37: 25-50

Liblik LK, Moore TR, Bubier JL and Robinson SD (1997) Methane emissions from wetlands in the zone of discontinuous permafrost: Fort Simpson, Northwest Territories, Cananda. Global Biogeochemical Cycles 11: 485-494

Liebner S and Wagner D (2007) Abundance, distribution and potential activity of methane oxidizing bacteria in permafrost soils from the Lena Delta, Siberia. Environ Microbiol 9: 107-117

Liebner S, Rublack K, Stuehrmann T, and Wagner D (2008) Diversity of aerobic methanotrophic bacteria in a permafrost soil of the Lena Delta, Siberia. Microb Ecol, under revision

Lin C, Raskin L and Stahl DA (1997) Microbial community structure in gastrointestinal tracts of domestic animals: comparative analyses using rRNA-targeted oligonucleotide probes. FEMS Microbiol Ecol 22: 281-294

Mathrani IM and Boone DR (1985) Isolation and characterization of a moderatly halophilic methanogen from a solar saltern. Appl Environ Microbiol 50: 140143

Metje $M$ and Frenzel $P$ (2007) Methanogenesis and methanogenic pathways in a peat from subarctic permafrost. Environ Microbiol 9: 954-964

Michaelson GJ, Ping CL and Kimble JM (1996) Carbon storage and distribution in tundra soils of Arctic Alaska, USA. Arctic and Alp Res 28: 414-424

Mohanty SR, Bodelier PLE, and Conrad R (2007) Effect of temperature on composition of the methanotrophic community in rice field and forest soil. FEMS Microbiol Ecol 62: 24-31

Morozova D, Möhlmann D and, Wagner D (2007) Survival of methanogenic archaea from Siberian permafrost under simulated Martian thermal conditions. Orig Life Evol Biosph 37: 189-200

Morozova D and Wagner D (2007) Stress response of methanogenic archaea from Siberian permafrost compared to methanogens from non-permafrost habitats. FEMS Microbiol Ecol 61: 16-25

Nelson FE, Anisimov OA, Shiklomanov NI (2001) Subsidence risk from thawing permafrost. Nature 410: 889-890

Oberbauer SF, Starr G and Pop EW (1998) Effects of extended growing and soil warming on carbon dioxide and methane exchange of tussock tundra in Alaska. Journal of Geophysical Research 103: 29,075-29,082 
Ochsenreiter T, Selezi D, Quaiser A, Bonch-Osmolovskaya L and Schleper C (2003) Diversity and abundance of Crenarchaeota in terrestrial habitats studied by 16S RNA surveys and real time PCR. Environ Microbiol 5: 787-797

Oechel WC, Hastings SJ, Jenkins M, Riechers G, Grulke NE and Vourlitis GL (1993) Recent change of arctic tundra ecosystems from a net carbon sink to a source. Nature 361: 520-526

Omelchenko MB, Vasieleva LV, Zavarzin GA, Savelieva ND, Lysenko AM, Mityushina LL, Khmelenina VN, and Trotsenko YA (1996) A novel psychrophilic methanotroph of the genus Methylobacter. Microbiology 65: 339343

Osterkamp TE (2001) Subsea Permafrost. In: Steele JH, Thorpe SA and Turekian KK (ed) Encyclopedia of Ocean Sciences, Academic Press, pp 2902-2912

Pacheco-Oliver M, McDonald IR, Groleau D, Murrell JC, and Miguez CB (2002) Detection of methanotrophs with highly divergent $p m o A$ genes from Arctic soils. FEMS Microbiol Lett 209: 313-319

Pancost RD, Steart DS, Handley L, Collinson ME, Hooker JJ, Scott AC, Grassineau NV, and Glasspool IJ (2007) Increased terrestrial methane cycling at the Paleocene-Eocene thermal maximum. Nature 449: 332-335

Panikov NS (1999) Understanding and predicting of soil microbial community dynamics under global change. Appl Soil Ecol 11: 161-176

Panikov NS and Dedysh SN (2000) Cold season $\mathrm{CH}_{4}$ and $\mathrm{CO}_{2}$ emission from boreal peat bogs (West Siberia) winter fluxes and thaw activation dynamics. Global Biogeochemical Cycles 14: 1071-1080

Pol A, Heijmans K, Harhangi HR, Tedesco D, Jetten MSM, Op den Camp HJM (2007) Methanotrophy below pH1 by a new Verrucomicrobia species. Nature 450: 874-878

Popp TJ, Chanton JP, Whiting GJ and Grant N (2000) Evaluation of methane oxidation in the rhizosphere of a Carex dominated fen in north central Alberta, Canada. Biogeochemistry 51: 259-281

Post WM, Emanuel WR, Zinke PJ, and Stangenberger AG (1982) Soil carbon pools and world life zones. Nature 298: 156-159

Raghoebarsing AA, Pol A, van de Pas-Schoonen KT, Smolders AJP, Ettwig KF, Rijpstra WI, Schouten S, Damsté JSS, Op den Camp HJM, Jetten MSM, and Strous M (2006) A microbial consortium couples anaerobic methane oxidation to dentrification. Nature 440: 918-921

Rahalkar M, Bussmann I, and Schink B (2007) Methylosoma difficile gen. nov., sp. nov., a novel methanotroph enriched by gradient cultivation from littoral sediment of Lake Constance. Intern J Syst Evol Microbiol 57: 1073-1080

Ramakrishnan B, Lueders T, Dunfield PF, Conrad R and Friedrich MW (2001) Archaeal community structures in rice soils from different geographical regions before and after initiation of methane production. FEMS Microbiol Ecol 37: 175-186

Reeburgh WS, King JY, Regli SK, Kling GW, Auerbach NA and Walker DA (1998) A $\mathrm{CH}_{4}$ emission estimate for the Kuparuk River basin, Alaska. Journal of Geophysical Research 103: 29,005-29,013

Rivkina, EM, Gilichinsky, D., Wagener, S., Tiedje, J. and McGrath, J.: 1998, Biochemical activity of anaerobic microorganisms from buried permafrost sediments, Geomicrobiol 15: 187-193

Roslev P, and King GM (1996) Regulation of methane oxidation in a freshwater wetland by water table changes and anoxia. FEMS Microbiol Ecol 19: 105-115 
Samarkin VA, Fedorov-Davydov DG, Vecherskaya MS and Rivkina EM (1994) $\mathrm{CO}_{2}$ and $\mathrm{CH}_{4}$ emissions on cryosols and subsoil permafrost and possible global climate changes In Soil processes and greenhouse effect, Lal R, Kimble JM, Levine E (eds) USDA Soil Conservation Service, National Soil Survey Center, Lincoln, NE; 55-71

Samarkin VA, Gundelwein A and Pfeiffer EM (1999) Studies of methane production and emission in relation to the microrelief of a polygonal tundra in northern Siberia. In Kassens H, Bauch HA, Dmitrenko IA, et al. (Eds) Land-Ocean Systems in the Siberian Arctic, Dynamics and History (pp 329-342). Springer, Berlin.

Schell DM and Ziemann PJ (1983) Accumulation of peat carbon in the Alaska Arctic coastal plain and its role in biological productivity. In: Permafrost: Fourth International Conference Proceedings, Fairbanks, Alaska. Washington DC, Nat'l Acad Sci, 1105-1110

Schimel JP and Gulledge J (1998) Microbial community structure and global trace gases. Global Change Biology 4: 745-758

Schink B and Stams AJM (2006) Syntrophism among Prokaryotes. In: Dworkin M, Falkow S, Rosenberg E, Schleifer K-H, Stackebrandt E (eds.) Prokaryotes, vol 2, Springer, New York, pp 309-335

Segers R (1998) Methane production and methane consumption: a review of processes underlying wetland methane fluxes. Biogeochemistry 41: 23-51

Slobodkin AI, Panikov NS and Zavarzin GA (1992) Formation and uptake of methane in tundra and boreal wetlands. Microbiology 61: 683-691

Simankova MV, Kotsyurbenko OR, Stackebrandt E, Kostrikina NA, Lysenko AM, Osipov GA, Nozhevnikova AN (2000) Acetobacterium tundrae sp. nov., a new psychrophilic acetogenic bacterium from tundra soil. Arch Microbiol 174:440447

Stendel M, Romanovsky VE, Christensen JH, and Sazonova T (2007) Using dynamical downscaling to close the gap between global change scenarios and local permafrost dynamics. Global Planetary Change 56: 203-214

Steven B, Briggs G, McKay CP, Pollard WH, Greer CW and Whyte LG (2007) Characterization of the microbial diversity in a permafrost sample from the Canadian high Arctic using culture-dependent and culture-independent methods. FEMS Microbiol Ecol 59: 513-523

Stoecker K, Bendinger B, Schöning B, Nielsen PH, Nielsen JL, Baranyi C, Toenshoff ER, Daims H, and Wagner M (2006) Cohn's Crenothrix is a filamentous methane oxidizer with an unusual methane monooxygenase. Proc Natl Acad Sci 14: 2363-2367

Svensson BH and Rosswall T (1984) In situ methane production from acid peat in plant communities with different moisture regimes in a subarctic mire. Oikos 43: $341-350$

Tarnocai C and Smith CAS (1992) The formation and properties of soils in the permafrost regions of Canada. In: Gilichinsky DA (ed) Crysols: The effects of cryogenesis on the processes and preculiarities of soil formation. Proceedings of the $1^{\text {st }}$ International Conference on Cryopedology, Pushchino, Russia, Russian Academy of Sciences, Inst of Soil Sci and Photosynthesis. 21-42

Torn MS and Chapin FS (1993) Environmental and biotic controls over methane flux from arctic tundra. Chemosphere 26: 357-368

Trotsenko YA and Khmelenina VN (2005) Aerobic methanotrophic bacteria of cold ecosystems. FEMS Microbiol Ecol 53: 15-26 
Tsubota J, Eshinimaev BT, Khmelenina VN, and Trotsenko YA (2005) Methylothermus thermalis gen. nov., sp. nov., a novel moderately thermophilic obligate methanotroph from a hot spring in Japan. Intern J Syst Evol Microbiol 55: $1877-1884$

Tsuyuzaki S, Nakano T, Kuniyoshi S and Fukuda M (2001) Methane flux in grassy marshlands near Kolyma River, north-eastern Siberia. Soil Biol Biochem 33: 1419-1423

Van der Nat FJWA and Middelburg JJ (1998) Seasonal variation in methane oxidation by the rhizosphere of Phragmites australis and Scirpus lacustris. Aquat Bot 61: 95-110

Vecherskaya MS, Galchenko VF, Sokolova EN and Samarkin VA (1993) Activity and species composition of aerobic methanotrophic communities in tundra soils. Current Microbiology 27: 181-184

Vourlitis GL, Oechel WC, Hastings SJ and Jenkins MA (1993) The effect of soil moisture and thaw depth on $\mathrm{CH} 4$ flux from wet coastal tundra ecosystems on the north slope of Alaska. Chemosphere 26: 329-337

Wagner D (2008) Microbial communities and processes in Arctic permafrost environments. In: Dion P. and Nautiyal C.S. (eds.): Microbiology of extreme soils. Soil Biology 13, Springer, Berlin, pp. 133-154

Wagner D, Kobabe S, Pfeiffer EM and Hubberten (2003) Microbial controls on methane fluxes from a polygonal tundra of the Lena Delta, Siberia. Permafrost Periglac Process 14: 173-185

Wagner D, Lipski A, Embacher A, and Gattinger A (2005) Methane fluxes in extreme permafrost habitats of the Lena Delta: effects of microbial community structure and organic matter quality. Environ Microbiol: 1582-1592

Wagner D, Gattinger A, Embacher A, Pfeiffer EM, Schloter M and Lipski A (2007) Methanogenic activity and biomass in Holocene permafrost deposits of the Lena Delta, Siberian Arctic and its implication for the global methane budget. Global Change Biology 13: 1089-1099

Walter BP, Heimann M, and Matthews E (2001) Modeling modern methane emissions from natural wetlands, 1 . Model description and results. J Geophys Res 106: 34,189-34,206

Wartiainen I, Hestnes AG, and Svenning MM (2003) Methanotrophic diversity in high arctic wetlands on the islands of Svalbard (Norway) - denaturing gradient gel electrophoresis analysis of soil DNA and enrichment cultures. Can J Microbiol 49: 602-612

Wartiainen I, Hestnes AG, McDonald IR, Svenning MM (2006a) Methylobacter tundripaludum sp. nov., a novel methanotrophic bacterium from Arctic wetland soil, Svalbard, Norway $\left(78^{\circ} \mathrm{N}\right)$. Intern J Syst Evol Microbiol 56: 109-113

Wartiainen I, Hestnes AG, McDonald IR, and Svenning MM (2006b) Methylocystis rosea sp. nov., a novel methanotrophic bacterium from Arctic wetland soil, Svalbard, Norway $\left(78^{\circ} \mathrm{N}\right)$. Intern J Syst Evol Microbiol 56: 541-547

Whalen SC and Reeburgh WS (1988) A methane flux time series for tundra environments. Global Biogeochemical Cycles 2: 399-409

Whalen SC and Reeburgh WS (1992) Interannual variations in tundra methane emission: A 4-year time series at fixed sites, Global Biogeochemical Cycles 6: 139-159

Whiting GJ and Chanton JP (1992) Plant-dependent $\mathrm{CH}_{4}$-emission in a subarctic Canadian fen. Global Biogeochem. Cycles 9: 225-231 
Wille C, Kutzbach L, Sachs T, Wagner D and Pfeiffer EM (2008) Methane emission from Siberian Arctic polygonal tundra: eddy covariance measurements and modeling. Global Change Biology, in press

Wise MG, McArthur JV, and Shimkets LJ (2001) Methylosarcina fibrata gen. nov. sp. nov. and Methylosarcina quisquiliarum sp. nov., novel type I methanotrophs. Intern J Syst Evol Microbiol 51: 611-621

Wuebbles J and Hayhoe K (2002) Atmospheric methane and global change. EarthSci Rev 57: 177-210

Yavitt JB, Williams CJ and Wieder RK (2000) Controls on microbial production of methane and carbon dioxide in three Sphagnum-dominated peatland ecosystems as revealed by a reciprocal field peat transplant experiment. Geomicrobiological Journal 17: 61-88

Zhang T, Barry RG, Knowles K, Heginbotton JA and Brown J (1999) Statistics and characteristics of permafrost and ground-ice distribution in the northern hemisphere. Polar Geography 23: 132-154

Zhang W, Parker KM, Lou Y, Wan S, Wallace LL, and Hu S (2005) Soil microbial response to experimental warming and clipping in a tallgrass prairie. Global Change Biol 11: 266-277

Zhuang Q, Melillo JM, Kicklighter DW Prinn, RG McGuire, AD Steudler, PA Felzer, BS and Hu S (2004) Methane fluxes between terrestrial ecosystems and the atmosphere at northern latitudes during past century: A retrospective analysis with a process-based biogeochemistry model. Glob Biogeochem Cyc 18: 3010 (23pp)

Zimov SA, Schuur EAG, and Chapin III FS (2006) Permafrost and the Global Carbon Budget. Science 312: 1612-1613

Zsolnay A (2003) Dissolved organic matter: artefacts, definitions, and functions. Geoderma 113: 187-209 